When the Lights Went OUt A History of Blackouts in America David E. Nye

Examining electricity's increasingly central role in American society, David Nye looks at power outages from 1935 to the present, not simply as technical failures but also variously as military tactics, social disruption, crisis in the networked city, the outcome of political and economic decisions and memories enshrined in photographs.

306 pp. (26 illus.)

$£ 20.95 \cdot$ cloth $\bullet$ 978-0-262-01374-1

\section{A VASt Machine}

Computer Models, Climate Data, and the Politics of Global Warming

\section{Paul N. Edwards}

Global warming skeptics often argue the need to wait for real data, that the case for global warming is based only on model predictions and simulations. In A Vast Machine Paul Edwards has news for these doubters: without models, there is no data. Today, no collection of signals or observations becomes global in time and space without passing through a series of data models. Edwards offers an engaging and innovative history of how scientists learned to understand the atmosphere - to measure it, trace its past, and model its future.

528 pp. (74 illus.) $\cdot$ May

$£ 24.95 \cdot$ cloth $\cdot 978-0-262-01392-5$

\section{THERMOPOETICS}

Energy in Victorian Literature and Science

Barri J. Gold

Charting the simultaneous emergence of the laws of thermodynamics in literature and in physics that began in the 1830s, Barri Gold finds that not only can science influence literature, but literature can influence science. Gold's original readings of works by Alfred Tennyson, Charles Dickens, Herbert Spencer, Bram Stoker and Oscar Wilde offer a decidedly literary introduction to elements of thermodynamic thought. 288 pp. (2 illus.)

$£ 22.95 \cdot$ cloth $\bullet$ 978-0-262-01372-7

\section{URBAN MODERNITY \\ Cultural Innovation in the Second Industrial Revolution}

Miriam R. Levin, Sophie Forgan, Martina Hessler, Robert H. Kargon and Morris Low

This book examines the invention of modernity through the construction of an urban-centered, industrial-based culture, by looking at the dynamic connecting urban planning, museums, educational institutions, and expositions in Paris, London, Chicago, Berlin and Tokyo from 1870 to 1930 .

304 pp. (25 illus.) $\cdot$ June

$£ 22.95 \cdot$ cloth $\cdot 978-0-262-01398-7$

\section{Crafting the Quantum Arnold Sommerfeld and the Practice of Theory, 1890-1926 \\ Suman Seth}

"This is a very impressive book, containing numerous new and innovative ideas and interpretations of the life and work of Arnold Sommerfeld and the school of students he led. A major contribution and a stirring history of some of the key players in quantum theory." - Andrew Warwick, Imperial College, London 368 pp. (24 illus.)

$£ 23.95 \cdot$ cloth $\bullet$ 978-0-262-01373-4

\section{TeChNOLOgY AND the Making OF THE NETHERLANDS \\ The Age of Contested Modernization, 1890-1970}

Edited by Johan Schot, Harry Lintsen and Arie Rip

This study offers an account of twentieth-century technology in the Netherlands and a view of Dutch history through the lens of technology. It describes the trajectory of modernisation through technology in certain characteristically Dutch contexts, but at the same time makes it clear that Dutch struggles over technology choices, infrastructure development, mass production and the role of government are comparable to the experience of any Western industrialised country.

$£ 26.95 \cdot 640$ pp. • cloth • 978-0-262-01362-8 


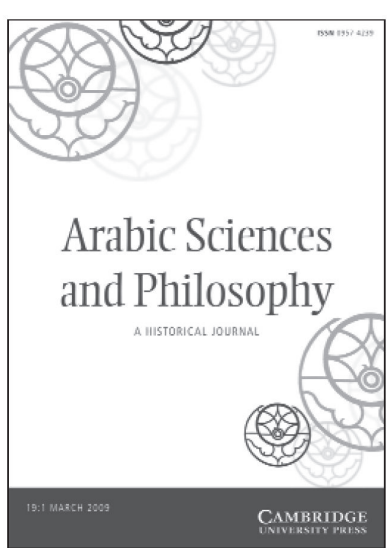

Arabic Sciences and Philosophy is available online at

http://journals.cambridge.org/asp

To subscribe contact

Customer Services

in Cambridge:

Phone +44 (0)1223 326070

$\mathrm{Fax}+44(0) 1223325150$

Email journals@cambridge.org

in New York:

Phone (845) 3537500

Fax (845) 3534141

Email

subscriptions_newyork@cambridge.org

Price information is available at

http://journals.cambridge.org/asp

\section{0th Volume in 2010}

\section{Arabic Sciences and Philosophy}

\author{
Executive Editors \\ Roshdi Rashed, CNRS, Paris, France \\ Basim Musallam, University of Cambridge, UK \\ Managing Editor \\ A. Hasnaoui, CNRS, Paris, France
}

\begin{abstract}
Arabic Sciences and Philosophy (ASP) is an international journal devoted to the Arabic sciences, mathematics and philosophy in the world of Islam between the eighth and eighteenth centuries, in a cross-cultural context. In 2009, the journal extended its scope to include important papers on scientific modernization from the nineteenth century in the Islamic world. Together with original studies on the history of all these fields, ASP also offers work on the inter-relations between Arabic and Greek, Indian, Chinese, Latin, Byzantine, Syriac and Hebrew sciences and philosophy. Casting new light on the growth of these disciplines, as well as on the social and ideological context in which this growth took place, ASP is essential reading for those interested in these areas.
\end{abstract}




\section{CAMBRIDGE}

\section{JOURNALS}

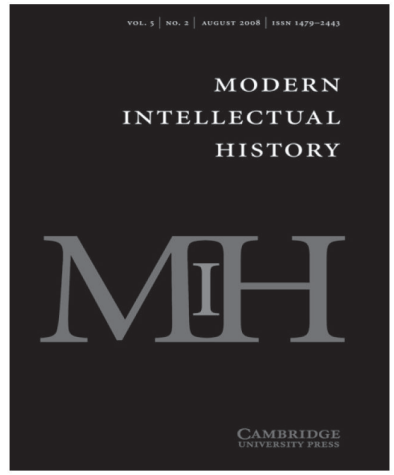

Modern Intellectual History

is available online at:

http:lljournals. cambridge.org/mih

To subscribe contact

Customer Services

in Cambridge:

Phone +44(0)1223 326070

Fax $+44(0) 1223325150$

Email journals@cambridge.org

in New York:

Phone +1 (845) 3537500

Fax +1 (845) 3534141

Email

subscriptions_newyork@cambridge.org

\section{MODERN INTELLECTUAL HISTORY}

\section{Editors}

Charles Capper, Boston University, USA

Anthony J. La Vopa, North Carolina State University, USA Samual Moyn, Columbia University, USA

Nicholas T. Phillipson, Edinburgh University, UK

This important journal serves as a focal point and forum for scholarship on intellectual and cultural history from the mid-seventeenth century to the present, with primary attention to Europe and the Americas and to transnational developments that encompass the non-West. Modern Intellectual History enquires into this era's intellectual discourses and texts, their ontextual origins and reception, and the recovery of their historical meanings.

Price information is available at: http://journals.cambridge.org/mih

Free email alerts

Keep up-to-date with new material - sign up at http://journals.cambridge.org/alerts 


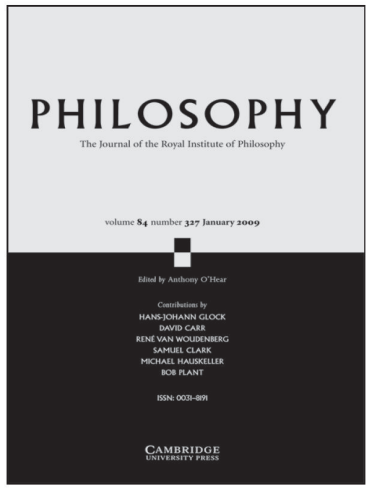

Philosophy

is available online at:

http:lljournals.cambridge.org/phi

To subscribe contact

Customer Services

in Cambridge:

Phone $+44(0) 1223326070$

$\mathrm{Fax}+44(0) 1223325150$

Email journals@cambridge.org

in New York:

Phone +1 (845) 3537500

$\mathrm{Fax}+1$ (845) 3534141

Email

subscriptions_newyork@cambridge.org

\section{PHILOSOPHY}

Published for the Royal Institute of Philosophy

\section{Editor}

Anthony O'Hear, University of Buckingham, UK

Philosophy is one of the leading academic journals of philosophy, but it also serves the philosophical interests of specialists in other fields (law, language, literature and the arts, medicine, politics, religion, science, education, psychology, history) and those of the general reader.

\section{Price information is available at:} http://journals.cambridge.org/phi

\section{Free email alerts}

Keep up-to-date with new material - sign up at http://journals.cambridge.org/alerts 


\section{CAMBRIDGE JDURNALS}

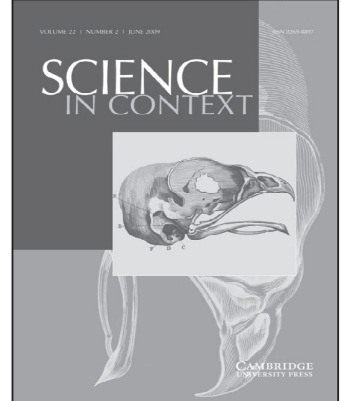

Science in Context

is available online at:

http:lljournals. cambridge.org/sic

To subscribe contact

Customer Services

\section{in Cambridge:}

Phone +44 (0)1223 326070

$\mathrm{Fax}+44(0) 1223325150$

Email journals@cambridge.org

\section{in New York:}

Phone +1 (845) 3537500

$\mathrm{Fax}+1$ (845) 3534141

Email

subscriptions_newyork@cambridge.org

\section{SCIENCE \\ IN CONTEXT}

\section{Editors}

Asaf Goldschmidt, Tel Aviv University, Israel

Alexandre Métraux, University of Mannheim, Germany

Jürgen Renn, Max-Planck-Institut für

Wissenschaftsgeschichte, Berlin, Germany

Science in Context is an international journal devoted to the study of the sciences from the points of view of comparative epistemology and historical sociology of scientific knowledge. The journal is committed to an interdisciplinary approach to the study of science and its cultural development.

Price information is available at: http://journals.cambridge.org/sic

Free email alerts

Keep up-to-date with new material - sign up at http://journals.cambridge.org/alerts 


\section{THE BRITISH SOCIETY FOR THE HISTORY OF SGIENGE}

Membership of the Society, which includes a subscription to The British Fournal for the History of Science, is open to all persons approved by the Council of the Society and elected at an ordinary meeting. The annual subscription for the membership year 2010 is $£ 41.00$ (\$66.00) or $£ 22.00$ (\$54.00 or $€ 32)$ for associate membership, which includes students at centres of higher education. There is an Introductory Offer for ordinary members who pay $£ 33.00(£ 66.00)$ for the first year. Applications for membership should be made on a form available from the Society's Executive Secretary at the address below. Payment may be made by cheque or credit card.

The British Journal for the History of Science is the official organ of the Society. All correspondence on the contents of the Journal should be addressed to the Editor, Jon Agar, Department of Science and Technology Studies, University College London, London WC1E 6BT, email ucrhjea@ucl.ac.uk

Book reviews: Books for review should be sent to the Reviews Editor, Dr Adam Mosley, School of Arts and Humanities: History and Classics, Swansea University, Singleton Park, Swansea, SA2 8PP, Wales, United Kingdom.

BSHS publications: BSHS Monograph Series is designed to allow the publication of monographic studies in the history of science quickly and cheaply. All correspondence on the subject of monographs should be sent to The Executive Secretary, 5 Woodcote Green, Fleet, Hants, GU51 4EY. Twelve monographs are currently available.

Recent titles are as follows:

Images of the Earth: Essays in the History of the Environmental Sciences. Edited by L. J. Jordanova and R. Porter. Second edition. 1997. £17.

Science in Art: Works in the National Gallery that illustrate the History of Science and Technology. By J. V. Field and F. A. J. L. James. 1997. £15.

To See the Fellows Fight: Eye-witness accounts of meetings of the Geological Society of London and its Club, 1822-1868. By J. C.Thackray. 2003. £15.

The Society's newsletter, Viewpoint, an informal publication, appears three times a year. It is free to members, $£ 10.00$ $(20.00)$ for institutions and non-members from the Executive Secretary.

Administrative business of the Society is handled by Lucy Tetlow, Executive Secretary, British Society for the History of Science, PO Box 3401, Norwich, NR7 7JF. The Society is registered in England as a Limited Company (No. 562208) and is a Registered Charity (No. 258854). Telephone and Fax (44) (0) 1252 641135. Email lucy.tetlow@bshs.org.uk.

Information about the Society is available through the Internet: http://www.bshs.org.uk

Copying: This journal is registered with the Copyright Clearance Center, 222 Rosewood Drive, Danvers, MA 09123. Organizations in the USA who are also registered with the CGC may therefore copy material (beyond the limits permitted by sections 107 and 108 of US copyright law) subject to payment to CCC of the per-copy fee of $\$ 12.00$. This consent does not extend to multiple copying for promotional or commercial purposes. Code 0007-0874/2010 $\$ 12.00$.

ISI Tear Sheet Service, 3501 Market Street, Philadelphia, Pennsylvania 19104, USA, is authorized to supply single copies of separate articles for private use only.

Organizations authorized by the Copyright Licensing Agency may also copy material subject to the usual conditions. Articles from the Journal in electronic or microfiche form can be obtained from Cambridge Journals Online (www.journals.cambridge.org), Proquest (www.proquest.com) and NAPC (www.napubco.com).

For all other use, permission should be sought from Cambridge University Press or from its American branch.

Advertising: Contact the Journals Advertising Manager, Cambridge University Press, The Edinburgh Building, Shaftesbury Road, Cambridge CB2 8RU.

Back volumes are obtainable as follows: Volumes 1-23: BSHS Executive Secretary, PO Box 3401, Norwich, NR7 7JF, UK. For Volume 24 onwards, apply to Cambridge University Press in printed form.

Information on the British fournal for the History of Science and all other Cambridge journals can be accessed via journals.cambridge.org

Claims for missing issues should be made immediately on receipt of the subsequent issue.

This journal issue has been printed on FSC-certified paper and cover board. FSC is an independent, non-governmental, not-for-profit organization established to promote the responsible management of the world's forests. Please see www.fsc.org for information.

Printed in the United Kingdom at the University Press, Cambridge 


\section{The British \\ Journal \\ for the \\ History of \\ Science}

Volume 43

Part I No. ${ }_{15} 6$

1 Scientific travel in the Atlantic world: the French expedition to Gorée and the Antilles, 1681-1683

NICHOLAS DEW

19 Conjectures and reputations: The composition and reception of James Bradley's paper on the aberration of light with some reference to a third unpublished version

JOHN FISHER

49 Giving wings to logic: Mary Everest Boole's propagation and fulfilment of a legacy

K. G. VALENTE

75 Postcolonial partnerships: deep sea research, media coverage and (inter)national narratives on the Galathea Deep Sea Expedition from 1950 to 1952

\section{KRISTIAN HVIDTFELT NIELSEN}

99 Obituary

105 Essay review: The role of an editor: some remarks on Whiteside's edition of Newton's mathematical papers

113 Essay review: Gardens of life and death

119 Book reviews

145 Books received

\section{B S H S}

THE BRITISH

SOCIETY FOR

THE HISTORY

OF SCIENCE

Published for The British Society for the History of Science

by Cambridge University Press 